\title{
UJI DAYA HAMBAT EKSTRAK ETANOL DAUN PANGI \\ (Pangium edule Reinw. ex Blume) TERHADAP BAKTERI Staphylococcus aureus, Escherichia coli DAN Pseudomonas aeruginosa
}

\section{THE INHIBITION TEST OF ETHANOL EXTRACT OF PANGI (Pangium edule Reinw. ex Blume) LEAVES AGAINTS Staphylococcus aureus, Escherichia coli AND Pseudomonos aeruginosa}

\author{
Glorya Sakul $^{1)}$, Herny Simbala ${ }^{1)}$, Gerald Rundengan ${ }^{1)}$ \\ ${ }^{1)}$ Program Studi Farmasi FMIPA UNSRAT Manado, 95115
}

\begin{abstract}
One of the natural ingredients that are often used as a medicinal plants is Pangi (Pangium edule Reinw. Ex Blume) plant. The part of pangi that are often used are leaves, which is known have antibacterial activity. North Sulawesi people empirically use this plant as food and to cure various diseases such as treating itching on the skin caused by bacteria found on the skin. The aim of this research was to determine and study the strength of antibacterial inhibition based on the category of inhibition by Davis and Stout of ethanol extract from pangi (Pangium edule Reinw. ex Blume) leaf performed by disc diffusion Kirby and Bauer method againts Staphylococcus aureus, Escherichia coli and Pseudomonos aeruginosa bacterias. The result showed that the ethanol extract from pangi (Pangium edule Reinw. Ex Blume) leaf has medium inhibitory strength at concentrations of 4\%, 6\% and $8 \%$.
\end{abstract}

Keywords: Pangium edule Reinw. ex Blume leaf, Antibacterial, Disc diffusion method

\begin{abstract}
ABSTRAK
Salah satu bahan alam yang sering digunakan sebagai tumbuhan obat adalah tumbuhan pangi (Pangium edule Reinw. ex Blume). Bagian dari tumbuhan pangi yang sering digunakan adalah bagian daun, dimana telah diketahui mempunyai aktivitas antibakteri. Masyarakat Sulawesi Utara secara empiris menggunakan tumbuhan ini sebagai bahan makanan serta untuk menyembuhkan berbagai penyakit seperti mengobati penyakit gatal-gatal pada kulit yang disebabkan oleh bakteri yang terdapat pada kulit. Penelitian ini bertujuan untuk mengetahui kekuatan daya hambat antibakteri berdasarkan kategori penggolongan daya hambat oleh Davis dan Stout dari ekstrak etanol daun Pangium edule Reinw. ex. Blume dengan metode difusi agar (difusi disk Kirby dan Bauer) terhadap bakteri uji Staphyloccocus aureus, Escherichia coli dan Pseudomonas aeruginosa. Hasil penelitian didapati bahwa ekstrak etanol daun Pangium edule Reinw ex. Blume mempunyai kekuatan daya hambat kategori sedang pada konsentrasi $4 \%, 6 \%$ dan $8 \%$.
\end{abstract}

Kata kunci: Daun Pangium edule Reinw. ex Blume, Antibakteri, Metode difusi disk 


\section{PENDAHULUAN}

Indonesia terletak di daerah katulistiwa yang mempunyai hutan hujan tropika yang dikenal cukup unik dan merupakan salah satu komunitas yang kaya akan keanekaragaman spesies tumbuhan di dunia. Indonesia memiliki \pm 30.000 jenis tumbuhan dan \pm 7000 jenis berkhasiat obat ( $90 \%$ jenis tumbuhan obat di kawasan Asia) (Rosoedarso, 1990).

Kekayaan keanekaragaman spesies yang dimiliki Indonesia merupakan potensi kandungan bahan-bahan kimia dan sumber daya genetika. Potensi ini merupakan keunggulan komparatif, karena pada saat ini terjadi peningkatan industri terhadap sumbersumber bahan kimia untuk memproduksi obatobatan, agrokimia, kosmetika, zat pewarna dan lain-lain. Potensi tersebut didukung oleh pengetahuan tradisional masyarakat tentang khasiatnya, menyebabkan Indonesia sebagai salah satu tujuan bagi pelaku bioprospeksi. Bioprospeksi pada prinsipnya adalah upaya pencarian, penelitian, pengumpulan, ekstrasi, dan pemilihan sumber daya hayati dan pengetahuan tradisional untuk mendapatkan materi genetik dan sumber biokimia yang bernilai ekonomi tinggi (Simbala, 2007).

Bangsa Indonesia telah lama mengenal tumbuhan obat. Begitu banyak tumbuhan obat yang tersedia di Indonesia termasuk di daerah Sulawesi Utara. Tumbuhan obat umumnya merupakan tumbuhan hutan yang sejak jaman nenek moyang telah menjadi tumbuhan pekarangan dan secara turun-temurun digunakan sebagai tumbuhan obat salah satunya adalah tumbuhan pangi (Simbala dan Edwin, 2015).

Tumbuhan pangi ini dapat dimanfaatkan sebagai obat tradisional, bagian daunnya sebagai sayuran, daging buahnya dapat dimakan jika sudah masak, dan bijinya dapat diolah sebagai bumbu masak, dapatjuga dimakan sebagai cemilan (Makagansa et al., 2015). Bagian daun tumbuhan pangi diketahui mengandung beberapa senyawa kimia seperti alkaloid, flavonoid, saponin, tanin dan terpenoid. Senyawa kimia inilah yang diduga berkhasiat sebagai antibakteri (Sangi et al., 2008).
Penelitian yang pernah dilakukan terkait khasiat dari tumbuhan ini yaitu uji aktivitas antibakteri dari ekstrak biji Pangi (Makagansa et al., 2015), uji aktivitas antibakteri ekstrak etil asetat daun Pangi (Mora et al., 2014), dan uji aktivitas antibakteri ekstrak etanol daun Pangi pada bakteri E.coli dengan metode dilusi cair (Pinta et al., 2017). Namun, belum pernah dilakukan penelitian uji aktivitas antibakteri yang lebih spesifik mengukur daya hambat atau kekuatan antibakteri dari ekstrak etanol terhadap bakteri Staphylococcus aureus, Escherichia coli dan Pseudomonas aeruginosa untuk bagian daun dari Pangi (Pangium edule Reinw. ex Blume) dengan metode pengujian secara difusi disk atau kertas cakram.

\section{METODOLOGI PENELITIAN}

\section{Waktu dan Tempat Penelitian}

Penelitian ini dilaksanakan mulai bulan November 2019 sampai Juni 2020. Tempat penelitian dilaksanakan di laboratorium farmasi lanjutan divisi Mikrobiologi Program Studi Farmasi Fakultas Matematikan dan Ilmu Pengetahuan Alam Universitas Sam Ratulangi.

\section{Bentuk Penelitian}

Penelitian ini merupakan penelitian yang bersifat eksperimental di laboratorium, dimana dibuat 5 perlakuan dan setiap perlakuan terdiri atas 3 pengulangan. Perlakuan dalam penelitian ini yaitu pemberian konsentrasi 4\%, 6\% dan 8\% pada ekstrak daun pangi (Pangium edule Reinw. ex Blume), kontrol positif Ciprofloxacin dan kontrol negatif akuades. Metode yang digunakan adalah metode difusi disk terhadap bakteri uji Staphylococcus aureus, Escherichia coli dan Pseudomonas aeruginosa.

\section{Alat dan Bahan}

Alat-alat yang digunakan dalam penelitian ini yaitu, alat-alat gelas (erlenmeyer, gelas piala, gelas ukur, 3 tabung reaksi, 9 cawan petri), autoklaf, inkubator, timbangan digital dan manual, LAF (Laminar Air Flow), hot plate, lampu bunsen, jarum inokulasi lurus, blender, lemari pendingin, mortar dan pestle, 
rak tabung, korek api, kapas, tissue,

evaporator, oven, cakram kertas $5 \mathrm{~mm}$, mikropipet $(10-1000 \mu \mathrm{L})$, jangka sorong, aluminium foil dan plastik wrap, kertas label, kamera, gunting, pinset, sarung tangan, masker.

Bahan-bahan yang diperlukan yaitu daun Pangi, bakteri Staphyloccocus aureus, Escherichia coli dan Pseudomonas aeruginosa, media Nutrient Agar (NA), akuades, $\mathrm{NaCl} 0.9 \%$, etanol $70 \%$, etanol $96 \%$ dan zat antibiotik (Ciprofloxacin).

\section{Pengambilan dan Penyiapan Sampel}

Sampel yang digunakan yaitu daun Pangi yang diambil di daerah Teling Tingkulu, Manado lalu dikumpulkan dan disimpan di plastik. Daun pangi disortir, dicuci dan ditimbang berat basah, kemudian dikeringkan dengan cara dikering-anginkan dalam suhu ruangan lalu ditimbang berat keringnya, setelah itu dihaluskan dengan blender menjadi serbuk simplisia halus lalu diayak dengan ayakan.

\section{Sterilisasi Alat}

Sterilisasi alat dilakukan sebelum semua peralatan digunakan, yaitu dengan cara membungkus semua peralatan dengan menggunakan kertas kemudian dimasukkanke dalam autoklaf pada suhu $121^{\circ} \mathrm{C}$ dengan tekanan 1 atm selama 15 menit. Alat yang tidak tahan panas tinggi disterilisasi dengan alkohol $70 \%$.

\section{Ekstraksi Sampel}

Ekstrak daun Pangi dibuat dengan cara maserasi. Dimana serbuk simplisia daun Pangi yang telah ditimbang dimasukkan ke dalam erlenmeyer/wadah gelas lainnya, kemudian direndam dengan pelarut etanol 96\%. Wadah ditutup dengan aluminium foil dan dibiarkan selama lima hari sambil sesekali diaduk. Setelah lima hari, sampel yang direndam tersebut disaring menggunakan kertas saring dan menghasilkan filtrat I dan ampas I. Ampas yang ada kemudian direndam lagi dengan larutan etanol $96 \%$, ditutup dengan aluminium foil dan dibiarkan selama dua hari sambil sesekali diaduk. Setelah dua hari, sampel tersebut disaring menggunakan kertas saring,

sehingga menghasilkan filtrat II dan ampas II. Filtrat I dan II digabungkan, kemudian dievaporasi menggunakan rotary evaporator, sehingga diperoleh ekstrak kental daun Pangi. Ekstrak kental yang dihasilkan dibiarkan pada suhu ruangan hingga seluruh pelarut etanol menguap. Setelah itu ekstrak ditimbang dan disimpan dalam wadah gelas tertutup sebelum digunakan untuk pengujian (Pinta et al., 2017).

\section{Pembuatan Media Pengujian Bakteri}

Media pengujian dibuat dengan cara ditimbang Nutrient Agar (NA) sebanyak 5,6 g, lalu dilarutkan dalam $200 \mathrm{~mL}$ akuades menggunakan wadah erlenmeyer. Media dihomogenkan dengan stirer diatas penangas air sampai mendidih. Media yang sudah homogen ini disterilkan dalam autoklaf pada suhu $121^{\circ} \mathrm{C}$ selama 15 menit, kemudian didinginkan sampai suhu $\pm 45-50{ }^{\circ} \mathrm{C}$.

\section{Pembuatan Suspensi Bakteri Uji}

Bakteri uji yang telah diinokulasi diambil dengan kawat ose steril lalu disuspensikan ke dalam tabung yang berisi 2 $\mathrm{mL}$ larutan $\mathrm{NaCl} \quad 0,9 \%$ hingga diperoleh kekeruhan yang sama dengan standar kekeruhan larutan Mc. Farland. Perlakuan yang sama dilakukan pada setiap jenis bakteri uji.

\section{Pembuatan Larutan Kontrol Positif}

Larutan kontrol positif dibuat dari sediaan obat tablet Ciprofloxacin $500 \mathrm{mg}$. Satu tablet Ciprofloxacin digerus lalu ditimbang $0,05 \mathrm{~g}$, kemudian dilarutkan dalam $50 \mathrm{~mL}$ akuades. Diambil $1 \mathrm{~mL}$ dari larutan tersebut dan ditambahkan akuades sampai $10 \mathrm{~mL}$, sehingga diperoleh larutan Ciprofloxacin dengan konsentrasi $1 \mu \mathrm{g} / 10 \mu \mathrm{l}$. Konsentrasi ini digunakan sebagai kontrol positif.

\section{Pembuatan Larutan Uji}

Dibuat larutan uji 4\%, 6\% dan $8 \%$ dengan cara ditimbang 0,04 g; 0,06 g; dan 0,08 $\mathrm{g}$ ekstrak etanol daun Pangi. Masing-masing ekstrak dilarutkan dalam $1 \mathrm{~mL}$ akuades. 


\section{Pembuatan Suspensi Bakteri Uji}

Bakteri uji yang telah diinokulasi diambil dengan kawat ose steril lalu disuspensikan ke dalam tabung yang berisi 2 $\mathrm{mL}$ larutan $\mathrm{NaCl} \quad 0,9 \%$ hingga diperoleh kekeruhan yang sama dengan standar kekeruhan larutan Mc. Farland. Perlakuan yang sama dilakukan pada setiap jenis bakteri uji.

\section{Pengujian Aktivitas Antibakteri}

Metode yang digunakan dalam penelitian ini adalah metode Kirby-Bauer, yaitu metode difusi dengan cakram kertas. Masing-masing dari suspensi bakteri Staphylococcus aures, Escherichia coli dan Pseudomononas aeruginosa sebagai biakan uji, dicampurkan pada medium NA kemudian campuran medium NA dan suspensi bakteri dituang ke 3 cawan petri steril sebanyak 20 $\mathrm{mL}$, cawan petri kemudian digoyang secara perlahan-lahan untuk menyebarkan biakan bakteri secara merata dan didiamkan hingga medium memadat (Rostinawati, 2009). Masing-masing dari cakram kertas steril dipindahkan secara aseptik menggunakan pinset steril ke konsentrasi yakni, 4\%, 6\%, dan $8 \%$ serta larutan antibiotik (kontrol positif) dan larutan akuades (kontrol negatif) direndam \pm 1 menit (Tangapo, 2005).

\section{Analisis Data}

Zona bening atau daya hambat dari diameter ekstrak etanol daun pangi yang terbentuk disajikan dalam bentuk tabel dan gambar. Penggolongan kekuatan antibakteri dari daya hambat yang diperoleh ekstrak etanol daun Pangi digolongkan berdasarkan penggolongan Davis dan Stout (1971).

\section{HASIL DAN PEMBAHASAN}

\section{Penyiapan Simplisia}

Bagian tumbuhan yang dipakai yaitu daun Pangi (Pangium edule Reinw. ex Blume) yang diperoleh sebanyak kurang lebih $2 \mathrm{~kg}$ sampel basah di daerah Teling Tingkulu, Manado, Sulawesi Utara.

Sebelum proses ekstraksi dilakukan, sampel dicuci terlebih dahulu dan dikeringkan dengan cara dikering-anginkan pada suhu ruangan kemudian dihaluskan dengan alat blender lalu diayak dengan ayakan agar memperoleh serbuk. Proses pencucian sampel dilakukan untuk memisahkan kotoran-kotoran atau bahan asing lainnya yang menempel pada sampel. Proses pengeringan sampel bertujuan untuk menghilangkan kadar air dalam sampel karena selain dapat mengganggu proses penarikan zat aktif, kadar air yang tinggi juga dapat membuat sampel mudah rusak oleh adanya pertumbuhan jamur. Proses pembuatan serbuk bertujuan untuk memperbesar luas permukaan kontak dengan pelarut sehingga proses ekstraksi bisa optimal. Sampel diayak bertujuan untuk menyeragamkan ukuran partikel, dimana keseragaman ukuran partikel ini dapat mempengaruhi keseragaman tahapan ekstraksi (Saifuddin et al., 2011).

\section{Ekstraksi Daun Pangi (Pangium edule Reinw ex. Blume)}

Daun Pangi yang diperoleh diekstraksi metode maserasi menggunakan pelarut etanol 96\%. Pemilihan pelarut etanol dalam penelitian ini karena menurut Herlianawati (2003), etanol dapat melarutkan senyawasenyawa yang bersifat nonpolar maupun yang bersifat polar seperti alkaloid, tanin, flavonoid, dan saponin. Senyawa-senyawa dari fenol, tanin, alkaloid dan saponin memiliki potensi sebagai antibakteri (Nakade et al., 2013). Setelah dimaserasi dengan etanol $96 \%$ selama 5 hari dan diremaserasi selama 2 hari, filtrat daun pangi yang dihasilkan berwarna hijaukehitaman. Hasil ekstraksi daun Pangium edule Reinw. ex Blume diperoleh sebanyak $650 \mathrm{~mL}$. Setelah dievaporasi dihasilkan filtrat kental ekstrak etanol sebanyak $20 \mathrm{~g}$.

\section{Uji Aktivitas Daya Hambat Ekstrak Etanol Daun Pangi (Pangium edule Reinw ex. Blume)}

Dalam menggolongkan daya hambat antibakteri ekstrak dilakukan pengukuran diameter zona hambat. Zona hambat berwarna bening yang terbentuk di sekitar kertas cakram yang diuji menandakan bahwa terjadi aktivitas daya hambat terhadap bakteri. Adanya zona hambat di sekitar kertas cakram merupakan daerah difusi dalam mempengaruhi 
pertumbuhan bakteri. Kekuatan antibakteri dapat diketahui dengan mengukur besarnya diameter dari zona hambat berwarna bening yang terbentuk oleh ekstrak yang diuji (Redwik et al., 2019).

Tabel 1. Rata-rata diameter zona hambat ekstrak daun Pangium edule Reinw terhadap Staphylococcus aureus, Escherichia coli dan Pseudomonas aeruginosa

\begin{tabular}{|c|c|c|c|c|c|c|c|c|c|c|c|c|}
\hline \multirow[t]{3}{*}{ Konsentrasi } & \multicolumn{12}{|c|}{ Diameter zona hambat pertumbuhan bakteri (mm) } \\
\hline & \multicolumn{4}{|c|}{ S.aureus } & \multicolumn{4}{|c|}{ E.coli } & \multicolumn{4}{|c|}{ P. aeruginosa } \\
\hline & U1 & $\mathrm{U} 2$ & U3 & Rata-rata & U1 & $\mathrm{U} 2$ & U3 & Rata-rata & U1 & $\mathrm{U} 2$ & $\mathrm{U} 3$ & Rata-rata \\
\hline $4 \%$ & 5,7 & 6,0 & 5,7 & 5,8 & 6 & 4,65 & 6,3 & 5,65 & 5,9 & 6,55 & 5,5 & 5,85 \\
\hline $6 \%$ & 5,7 & 6,45 & 6 & 6,05 & 6,55 & 4,8 & 6,1 & 5,81 & 6 & 5 & 6,55 & 6,35 \\
\hline $8 \%$ & 8,3 & 8,4 & 6,1 & 7,6 & 5,9 & 6 & 6,55 & 6,55 & 7 & 6,55 & 7,05 & 6,5 \\
\hline Kontrol (+) & 28,5 & 28,3 & 28 & 28,26 & 26,65 & 26,1 & 25,9 & 26,22 & 25,9 & 24 & 26,1 & 25,33 \\
\hline Kontrol (-) & 0 & 0 & 0 & 0 & 0 & 0 & 0 & 0 & 0 & 0 & 0 & 0 \\
\hline
\end{tabular}

Hasil pengujian dari ekstrak etanol daun Pangium edule Reinw. ex Blume terhadap bakteri Staphylococcus aureus, terlihat memiliki zona hambat di konsentrasi 4\%, 6\% dan 8\% masing-masing sebesar 5,8 $\mathrm{mm}, 6,05 \mathrm{~mm}$ dan 7,6 $\mathrm{mm}$ (Tabel 1). Kemampuan menghambat dari ketiga konsentrasi ekstrak lebih lemah daripada kemampuan menghambat dari kontrol positif yaitu antibiotika ciprofloxacin yang memiliki zona hambat sebesar 28,26 mm.

Hasil pengujian dari ekstrak etanol daun Pangium edule Reinw. ex Blume terhadap bakteri Escherichia coli, terlihat memiliki zona hambat di konsentrasi $4 \%, 6 \%$ dan $8 \%$ masing-masing sebesar $5,65 \mathrm{~mm}, 5,81$ $\mathrm{mm}$ dan 6,55 mm (Tabel 1). Kemampuan menghambat dari ketiga konsentrasi ekstrak lebih lemah daripada kemampuan menghambat dari kontrol positif yaitu antibiotika ciprofloxacin yang memiliki zona hambat sebesar 26,22 $\mathrm{mm}$.

Hasil pengujian dari ekstrak etanol daun Pangium edule Reinw. ex Blume terhadap bakteri Pseudomonas aeruginosa, terlihat memiliki zona hambat di konsentrasi 4\%, 6\% dan 8\% masing-masing sebesar 5,85 $\mathrm{mm}, 6,35 \mathrm{~mm}$ dan 6,5 $\mathrm{mm}$ (Tabel 1). Kemampuan menghambat dari ketiga konsentrasi ekstrak jauh lebih lemah daripada kemampuan menghambat dari kontrol positif yaitu antibiotika ciprofloxacin yang memiliki zona hambat sebesar 25,33 $\mathrm{mm}$.

Dari hasil pengamatan dan pengukuran penelitian ini, kontrol positif antibiotika ciprofloxacin yang digunakan mempunyai zona hambat yang paling besar diameternya daripada zona hambat yang terbentuk dari pengujian pada ketiga jenis bakteri uji dengan ketiga jenis konsentrasi masing-masing. Menurut Jawetz et al. (2007), antibiotik ini memiliki efek antibakteri yang besar (spektrum luas), sehingga memiliki aktivitas penghambatan yang sangat kuat untuk ketiga jenis bakteri uji.

Suatu ekstrak atau tanaman perlu diketahui kekuatan antibakterinya. Menurut Davis dan Stout (1971), untuk kekuatan bakteri dapat dikelompokkan seperti pada tabel berikut:

Tabel 2. Kategori daya hambat bakteri menurut Davis-Stout

\begin{tabular}{cc}
\hline Daya hambat bakteri & Kategori \\
\hline$\geq 20 \mathrm{~mm}$ & Sangat kuat \\
$10-20 \mathrm{~mm}$ & Kuat \\
$5-10 \mathrm{~mm}$ & Sedang \\
$\leq 5 \mathrm{~mm}$ & Lemah \\
\hline
\end{tabular}

Berdasarkan kriteria pada Tabel 2, maka daya hambat antibakteri dari ekstrak 
etanol daun Pangium edule Reinw. ex Blume terhadap bakteri Staphylococcus aureus dengan konsentrasi 4\%, 6\% dan $8 \%$ termasuk dalam kategori sedang. Daya hambat antibakteri terhadap bakteri Escherichia coli dengan konsentrasi ekstrak 4\%, 6\% dan $8 \%$ juga termasuk sedang. Demikian juga daya hambat antibakteri terhadap bakteri Pseudomonas aeruginosa dengan konsentrasi ekstrak 4\%, 6\% dan 8\% termasuk kategori sedang juga. Dengan demikian, dapat diketahui bahwa dalam ketiga konsentrasi ekstrak yang digunakan untuk bakteri Staphylococcus aureus, Escherichia coli dan Pseudomonas aeruginosa, menandakan bahwa ekstrak ini memiliki aktivitas sebagai antibakteri dengan daya hambatan pada kategori sedang. Data hasil penggolongan dari pengujian ini dapat dilihat pada Tabel 3 berdasarkan masing-masing konsentrasinya.

Tabel 3. Data hasil kategori golongan daya hambat 3 jenis bakteri uji dari pengujian ekstrak etanol daun Pangi (Pangium edule Reinw. ex Blume)

\begin{tabular}{ccc}
\hline Bakteri Uji & Konsentrasi & $\begin{array}{c}\text { Kategori } \\
\text { Golongan } \\
\text { Daya } \\
\text { Hambat }\end{array}$ \\
\cline { 3 - 3 } Staphylococcus & $4 \%$ & $\begin{array}{c}\text { Sedang } \\
\text { aureus }\end{array}$ \\
\hline Escherichia & $8 \%$ & Sedang \\
coli & $4 \%$ & Sedang \\
\hline Pseudomonas & $6 \%$ & Sedang \\
aeruginosa & $6 \%$ & Sedang \\
& $6 \%$ & Sedang \\
\hline
\end{tabular}

Dari hasil pengujian terhadap ketiga jenis bakteri uji, diketahui bahwa daya hambat antibakteri ekstrak etanol daun Pangium edule Reinw. ex Blume terhadap bakteri Escherichia coli, memiliki diameter zona hambat yang paling kecil untuk ketiga konsentrasi yaitu $4 \%$ $(5,65 \mathrm{~mm}), 6 \%(5,81 \mathrm{~mm})$ dan $8 \%(6,55 \mathrm{~mm})$ apabila dibandingkan dengan bakteri Pseudomonas aeruginosa yaitu 4\% (5,85 mm), $6 \%(6,35 \mathrm{~mm})$ dan $8 \%(6,5 \mathrm{~mm})$ dan juga dengan bakteri Staphylococcus aureus yang memiliki diameter zona hambat yang paling besar dari antara ketiga jenis bakteri uji yaitu $4 \%(5,8 \mathrm{~mm}), 6 \%(6,05 \mathrm{~mm})$ dan 8\% (7,6 mm) walaupun ketiganya memiliki kategori daya hambat yang sama yaitu golongan sedang.

Daya hambat dari ekstrak etanol daun Pangium edule Reinw. ex Blume terhadap bakteri gram negatif (Escherichia coli dan Pseudomonas aeruginosa) memiliki aktivitas antibakteri yang tergolong sedang. Demikian juga daya hambat dari ekstrak etanol daun pangi terhadap bakteri gram positif (Staphylococcus aureus) memiliki aktivitas antibakteri yang tergolong sedang. Walaupun pada ketiga bakteri uji memiliki kategori daya hambat ekstrak etanol daun pangi yang sama yaitu pada golongan sedang, namun hasil pengukuran diameter daya hambat rata-rata ketiga bakteri uji dapat diketahui bahwa aktivitas antibakteri ekstrak etanol pangi lebih kuat terhadap bakteri gram positif dalam hal ini bakteri Staphylococcus aureus dibandingkan dengan bakteri gram negatif yaitu bakteri Escherichia coli dan Pseudomonas aeruginosa. Hal ini menunjukkan bahwa bakteri gram positif lebih rentan terhadap ekstrak etanol daun pangi dibandingkan dengan bakteri gram negatif.

Dewi (2010) melaporkan bahwa perbedaan sensitivitas bakteri terhadap antibakteri dipengaruhi oleh struktur dinding sel bakteri. Struktur dinding sel gram positif lebih sederhana dibandingkan struktur dinding sel bakteri gram negatif sehingga memudahkan senyawa antibakteri untuk masuk ke dalam dinding sel bakteri gram positif. Bakteri gram positif memiliki struktur dinding sel dengan lebih banyak peptidoglikan, sedikit lipid dan dinding sel mengandung polisakarida (asam teikoat). Asam teikoat merupakan polimer yang larut dalam air, yang berfungsi sebagai transport ion positif untuk keluar atau masuk. Sifat larut air inilah yang menunjukkan bahwa dinding sel bakteri gram positif bersifat lebih polar, sedangkan senyawa fenolik dalam pangi merupakan bagian yang bersifat polar sehingga lebih mudah menembus lapisan peptidoglikan yang bersifat polar daripada lapisan lipid yang nonpolar. Itulah sebabnya aktivitas penghambatan pada bakteri gram positif lebih besar daripada bakteri gram negatif. 
Menurut Ajizah (2004), kemampuan suatu bahan antimikroba dalam meniadakan kemampuan hidup mikroorganismetergantung pada konsentrasi dan jenis bahan antimikroba itu sendiri. Hasil penelitian dari pengujian ekstrak daun pangi ini menunjukkan bahwa aktivitas penghambatan yang terbesar ada pada konsentrasi ekstrak $8 \%$ untuk semua bakteri uji. Ini membuktikan bahwa semakin tinggi konsentrasi ekstrak daun pangi yang diberikan maka semakin besar pula daya hambat yang ditimbulkan, karena pada konsentrasi yang lebih besar semakin banyak zat antibakteri yang terkandung di dalam ekstrak.

Zona hambat yang terbentuk dari hasil pengujian daya hambat ekstrak etanol daun pangi diketahui tidak termasuk dalam golongan yang kuat. Diameter zona hambat yang terbentuk dapat disebabkan oleh berbagai faktor seperti dalam proses pembuatan larutan uji ekstrak daun pangi yang dilarutkan dengan larutan akuades tidak mendapatkan kelarutan yang sempurna. Kesempurnaan kelarutan akan terjadi apabila pembuatan larutan uji dilakukan pengenceran terlebih dahulu dari konsentrasi terbesar hingga terkecil sehingga kertas cakram dapat menyerap juga dengan sempurna pada larutan uji yang telah larut sempurna. Selain itu, penggunaan akuades sebagai pelarut terakhir dalam larutan uji akan mempengaruhi proses pengujian, karena akuades yang bersifat polar hanya dapat melarutkan senyawa antibakteri yang bersifat polar sehingga senyawa-senyawa antibakteri yang bersifat non polar kemungkinan tidak larut dan tidak bekerja sepenuhnya untuk menghambat pertumbuhan bakteri pada tahap pengujian. Faktor lainnya yang dapat menyebabkan diameter zona hambat tidak terlalu besar yaitu karena pada tahap sebelum pengujian, belum dilakukan pengukuran $\mathrm{pH}$ pada media NA (Nutrient Agar) yang akan digunakan sebagai pertumbuhan bakteri sehingga bakteri uji yang digunakan kurang bertumbuh secara optimal. Menurut Haastuti (2008), beberapa faktor abiotik yang dapat mempengaruhi pertumbuhan bakteri, antara lain: suhu, kelembaban, cahaya, $\mathrm{pH}$, dan nutrisi. Apabila faktor-faktor abiotik tersebut memenuhi syarat, sehingga optimum untuk pertumbuhan bakteri, maka bakteri dapat tumbuh dan berkembang biak.

Penelitian yang pernah dilakukan terkait khasiat tumbuhan ini yaitu uji daya hambat aktivitas antibakteri ekstrak akuades biji pangi memberikan hasil bahwa konsentrasi yang bisa menunjukkan efek penghambatan yang baik untuk bakteri Staphylococcus aureus adalah konsentrasi ekstrak 4\%, 6\% dan 8\% dengan aktivitas penghambatan yang kuat dan sangat kuat, untuk bakteri Bacillus cereus, konsentrasi ekstrak 2\%, 4\%, dan 6\% sudah menunjukkan efek penghambatan yang kuat dan pada konsentrasi $8 \%$ sangat kuat. Sedangkan untuk bakteri gram negatif seperti Escherichia coli dan Pseudomonas aeruginosa konsentrasi $2 \%$ belum menunjukkan aktivitas penghambatan yang baik, tetapi konsentrasi $4 \%, 6 \%$ dan $8 \%$ sudah menunjukkan aktivitas yang kuat (Makagansa et al., 2015).

Penelitian yang dilakukan oleh Pinta et al. (2017) yaitu uji Kadar Hambat Minimum (KHM) dan Kadar Bunuh Minimum (KBM) dan identifikasi fitokimia dari ekstrak etanol daun pangi terhadap pertumbuhan bakteri Escherichia coli dengan metode dilusi. KHM ekstrak daun pangi terdapat pada konsentrasi $25 \%$ dan KBM ekstrak daun pangi belum dapat ditentukan karena sampai konsentrasi 50\% masih menunjukan adanya pertumbuhan bakteri. Berdasarkan hasil skrinning fitokimia, diperoleh hasil bahwa ekstrak etanol daun pangi mengandung senyawa flavonoid, saponin dan steroid. Senyawa-senyawa dari penelitian tersebut yang memungkinkan bekerja sebagai antibakteri terhadap ketiga bakteri uji dari penelitian ini yaitu S.aureus, E.coli dan $P$. aeruginosa.

Penelitian yang berkaitan juga dengan penelitian ini adalah dari Mora et al. (2014) tentang isolasi dan uji aktivitas antibakteri ekstrak etil asetat daun kepayang. Uji aktivitas antibakteri dilakukan dengan metode difusi agar pada konsentrasi 5\%, 10\% dan 20\% terhadap bakteri Staphylococcus aureus dan Escherichia coli aktivitasnya dikategorikan tingkat lemah sedangkan aktivitas senyawa hasil isolasi yang didapat yaitu senyawa steroid pada konsentrasi $1 \%$ dan $2 \%$ tidak 
menunjukkan aktivitas terhadap bakteri Staphylococcus aureus dan Escherichia coli.

\section{KESIMPULAN}

Berdasarkan penelitian yang telah dilakukan dapat disimpulkan bahwa ekstrak etanol daun Pangi (Pangium edule Reinw ex. Blume) memiliki aktivitas sebagai antibakteri terhadap Staphylococcus aureus, Escherichia coli dan Pseudomonas aeruginosa dengan metode difusi. Konsentrasi 4\%, 6\%, dan $8 \%$ merupakan konsentrasi yang termasuk dalam golongan daya hambat sedang untuk menghambat ketiga bakteri uji tersebut.

\section{SARAN}

Diharapkan untuk penelitian yang lebih lanjut mengenai metode difusi disk atau cakram Kirby-Bauer dari ekstrak etanol daun pangi (Pangium edule Reinw. ex Blume) terhadap bakteri uji Staphylococcus aureus, Escherichia coli dan Pseudomonas aeruginosa menggunakan konsentrasi yang lebih tinggi agar bisa mendapatkan kekuatan daya hambat yang lebih besar. Juga sebaiknya dilakukan isolasi senyawa fitokimia yang bersifat antibakteri terlebih dahulu dari ekstrak tersebut sebelum dilakukan pengujian.

\section{DAFTAR PUSTAKA}

Ajizah, A. 2004. Sensitivitas Salmonella typhimurium Terhadap Ekstrak Daun Psidium Guajava L. Bioscientiae. 1(1).

Davis dan Stout. 1971. Disc Plate Method Of Microbiological Antibiotic Essay. Journal Of Microbiology. 22(4).

Dewi, F. K. 2010. Aktivitas Antibakteri Ekstrak Etanol Buah Mengkudu (Morinda citrifolia, L) terhadap Bakteri Pembusuk Daging Segar. [Skripsi]. USM, Surakarta.

Haastuti, U. S. 2008. Petunjuk Praktikum Mikrobiologi. Universitas Negeri Malang, Malang.
Herlianawati, M. 2003. Uji Potensi Antibakteri Ekstrak Etanol Umbi Binahong (Anredera cordifolia (Tenore) Steen) terhadap Staphylococcus aureus ATCC 25923 dan Pseudomonas aeruginosa ATCC 27853, [skripsi]. Universitas Sanata Dharma, Depok.

Jawetz, E. Melnick, J. L dan Adelberg, E.A. 2007. Mikrobiologi Kedokteran Edisi 23. Salemba Medika, Jakarta.

Makagansa, C., Mamuaja, C. F., dan Mandey, L. C. 2015. Kajian Aktivitas Antibakteri Ekstrak Biji Pangi (Pangium Edule Reinw) Terhadap Staphylococcus aureus, Bacillus cereus, Pseudomonas aeruginosa Dan Escherichia coli Secara In Vitro. Jurnal Ilmu dan Teknologi Pangan. 3(1): 16-25.

Mora, K., Emrizal., dan Mulyantika, E. 2014. Isolasi Senyawa dan ekstrak etil asetat daun kepayang (Pangium edule Reinw ex. Blume) dan uji aktivitas antibakteri. Farmasains. 2(3).

Nakade, D. B., Mabesh, S. K., Kiran, N. P., dan Vinayak, S. M. 2013. Phytochemical Screening and Antibacterial of Western Region Wild Leaf Colocasia esculania. International Research Journal of Biology Sciences. 2 (10) : 2278-3202.

Pinta., Lolo, W. A., dan Yamlean, P. V. Y. 2017. Identifikasi Kandungan Fitokimia Dan Uji Kadar Hambat Minimum Dan Kadar Bunuh Minimum Ekstrak Etanol Daun Pangi (Pangium Edule Reinw ex. Blume) Terhadap Pertumbuhan Bakteri Escherichia coli. Pharmacon. 6(3): 260267.

Redwik, D. U. W., Simbala, H. E dan Edy, H. J. Identifikasi Fitokimia dan Uji Daya Hambat Dari Ekstrak Etanol Tangkai Buah Pinang Yaki (Areca vestiaria giseke) Terhadap Bakteri Staphylococcus aureus, Escherichia coli Dan Pseudomonas aeruginosa. Pharmacon. 8(4): 89-98. 
Roseoedarso. 1990. Pengantar Ekologi. Remaja Rosdakarya, Bandung.

Rostinawati, T. 2009. Aktivitas Antibakteri Etanol Bunga Rosella (Hibiscus sabdarifa L.) Terhadap Escherichia coli, Salmonella typhi Dan Staphylococcus aureus Dengan Metode Difusi Agar. Penelitian Mandiri: Fakultas Famasi, Universitas Padjajaran.

Saifuddin, A., Rahayu, V., dan Teruna, H. Y. 2011. Standarisasi Bahan Obat Alam. Graha Ilmu, Jakarta.

Sangi, M., Runtuwene, M. R. J., dan Simbala, H. E. I. 2008. Analisis Fitokimia Tumbuhan Obat Di Kabupaten Minahasa Utara. Chem. Prog. 1(1).

Simbala, H. E. I. 2007. Keanekaragaman Floristik Dan Pemanfaatannya Sebagai
Tumbuhan Obat Di Kawasan Konservasi II Taman Nasional Bogani Nani Wartabone (Kabupaten Bolaang Mongondow Sulawesi Utara). [disertasi]. Institut Pertanian Bogor, Bogor.

Simbala, H. E. I., dan Edwin de Queljoe. 2015. Biodiversitas Tumbuhan Obat di Sulawesi Utara. CV. Patra Media Grafindo, Bandung.

Tangapo, A. M. 2005. Efektivitas Antibakteri Ekstrak Tumbuhan Daun Sendok (Plantago major) Terhadap Staphylococcus aureus Dan Pseudomonas aerugiosa [skripsi]. Universitas Sam Ratulangi, Manado. 